\title{
Themes and content of the 2012 London Olympic Games Opening Ceremony: a comparison between pre-Games perspectives of British residents perceptions and actual ceremonial elements.
}

Konstantaki M. ${ }^{1}$, Wickens, E. ${ }^{2}$ Perris, F-Y. ${ }^{3}$

${ }^{1}$ Department of Advanced Health and Exercise Sciences, Buckinghamshire New University, UK; ${ }^{2}$ Department of Tourism and Environmental Studies, Universiti Utara, Malaysia; ${ }^{3}$ Department of Food and Tourism Management, Manchester Metropolitan University, UK

Tourism and Hospitality Research (2016), 1: 1-14. DOI: 10.1177/1467358416683766

\begin{abstract}
The focus of this paper is the London 2012 Olympic Games Opening Ceremony. More specifically, this article examines the pre-Games views of a sample of 301 British residents (57.8\% male, $42.2 \%$ female; age range: $18-65$ years) on imagined themes and content of the Opening Ceremony. In addition, the paper discusses the perceptions of cultural identity, i.e. 'Britishness' of the surveyed population. The link between the imagined and actual representation of cultural elements is analysed to investigate the importance of local residents' perspectives in the planning of the Opening Ceremony of the London 2012 Olympic Games. The paper also argues residents' perceptions of contemporary culture in Britain as "an amalgamation of British and ethnic minority cultures" and its impact on shaping the meaning of 'Britishness'. The findings of this study propose important managerial implications for planning of Olympic Games Opening Ceremonies while they may also be useful in planning of other national events. Cultural performances which highlight the mainstay feature of a country help to develop a realistic and accurate national identity to international audiences which could potentially increase tourism visits.
\end{abstract}

Key words: Olympic Games, London 2012, Opening Ceremony, ceremonial themes, British culture 


\section{Introduction}

As a mega sport event the Olympic Games are watched by an audience of millions worldwide, the Opening Ceremony of an Olympic Games is a great opportunity for each host city and country to publicise their icons, promote their image and identity and showcase the country's culture and tradition at the regional and national level (Tomlinson, 1996). According to BBC commentator for the Los Angeles 1984 Olympic Games Opening Ceremony, David Coleman, to stage the host nation's culture, history, music and dance during the ceremonial presentation has been one of the Olympic ceremonial traditions (Tomlinson, 1996). The way of conveying the image of a host city's culture and history varies from one country to another, which makes each Opening Ceremony unique (Sealy and Wickens, 2008). For instance, the Summer Olympic Opening Ceremony in Athens projected 'new Greece' to the global audience (Traganou, 2010), whereas Manzenreiter (2010) commented that China used the Beijing Olympic Games to promote 'Cultural China' and 'Modern China' for its national identity.

Every host nation aims to greet and impress an international audience, in order to try and stay at the forefront of the world's admiration and attention (Arning, 2013). Especially, the artistic program of the Olympic Games Opening Ceremonies is used to depict and foster national identity and culture (Xin, 2006). As listed in the Olympic Charter, the first version of which is estimated to have been published in 1898, the expression of universal ideas of humanism and peaceful internationalism must be a part of the artistic component in addition to the expression of the host nation's identity and culture (Chatziefstathiou, 2005). Most of the ceremonies are designed to highlight the Olympism with the celebration of the country's unique characteristics. However, despite the extravagant celebration shown in Beijing 2008 ceremonies, the Chinese failed to impress Western publics as the ceremonies 
were cross-referenced with Olympism and the concept of human civilisation. The ceremonies were perceived to lack transparency and were very much centralised and staged which did not show the reality of China (Mobley, 2008; Manzenreiter, 2010). Arguably, the staged national identities in the ceremonies represent the 'what' and 'how' the nation understands the shared projection of nationhood.

During an Olympic Opening Ceremony, each host nation tries to present their artistic program in a creative and transformative way (Traganou, 2010) incorporating history and cultural traditions. For instance, the Opening Ceremonies of the Barcelona 1992, Lillehammer 1994 and Athens 2004 Olympic Games displayed the highlights of their regional and national cultural identities including music and dance which showcased their uniqueness and "authenticity" (Moragas, 2009). In search of authenticity through performance, it is argued that authenticity as a concept is established and modified through embodied practice which illustrates rituals and traditions of a place (Rickly-Boyd, 2012). An Olympic Games Opening Ceremony provides a platform for host nations to perform a variety of rituals, music, folk, dance and traditions as a constructed image to communicate with audiences.

With the notion of 'performative authenticity' (Zhu, 2012), the bright colours and Mediterranean values marked the festive nature of the Opening Ceremony in Barcelona. The human mosaic forming the word "Hola" inspired by Gaudí's modernist mosaics was particularly spectacular. Another striking performance was the show by the theatre company "La Fura del Baus" showing the ship transporting the statesmen, warriors and athletes who, despite the setbacks and with the help of Hercules, managed to arrive safely at their destination (Barcelona Olímpica, 1992). In Lillehammer, the 1994 Winter Olympic Games 
Opening Ceremony showcased Norwegian culture which reflected Norway's variety of tradition, culture and heritage (Klausen, 1999). The main elements were 'simplicity, dignity and popularity' which represented the authenticity and unadulterated Norwegianess and made the event one of the most 'memorable' in Olympic Opening Ceremonies history (Pujik, 1999). Held at the ski jumping hill, Lysgårdsbakken, the artistic content represented a range of Norwegian culture and included traditional Sami singing (joik), telemark skiing (a ski technique that combines elements of Alpine and Nordic skiing), fiddlers and folk dancing, simulations of traditional weddings and their processions, and creatures from Norse mythology (LOOC, 1994).

In Olympia, Greece, the birthplace of the ancient Olympics in $776 \mathrm{BC}$ and the host of the first modern Games in 1896, the Opening Ceremony of the 2004 Games created an uplifting atmosphere that aimed at boosting the nation's pride. The stadium's arena was converted into an artificial lake and hosted the two key segments of the Opening Ceremony entitled 'Allegory' and 'Clepsydra'. Allegory included a series of projections on the theme of shared humanity and universalism, whereas prehistoric paintings such as Clepsydra were brought to life through enactment and continued with archaic, classical, Byzantine, Ottoman and modern artistic forms (Traganou, 2010). The creative director of the event, Dimitris Papaioannou, stated that the event "was a pageant of traditional Greek culture and history dating back to its mythological beginnings that was viewed through the progression of Greek art". The dramatic music that accompanied the performances often combined drumming with the traditionally Greek sound of bouzouki. Athenians showed their delight in welcoming the Olympics back, giving the 9,000 performers a rousing reception as the theatrical show came to a close before welcoming the athletes (BBC, 2004).

More recently, the Beijing 2008 Olympic Games Opening Ceremony showcased Chinese 
culture and tradition by exhibiting Chinese civilization and modern China's dream of harmony between the people of the world (Xu, 2008), while the display of history and development of Beijing were promoted as the new image of China to the worldwide audience (Weed, 2008). The time and date of the opening ceremony was cleverly chosen by the Chinese ( $8 \mathrm{pm}$ on $8^{\text {th }}$ August 2008$)$ to celebrate the auspicious number 8 that, according to Chinese culture, is associated with prosperity and confidence. Cook and Miles (2010) described this Opening Ceremony as 'spectacular' and also stated that as a modern mega event the Beijing Olympic Games would prove to be difficult for London and subsequent successors to live up to, not least because of the global economic recession. It was the magnificent spectacular cultural show in the Opening Ceremony of the Beijing 2008 Games that inspired the authors of this paper to undertake the study of the 2012 London Olympic Games Opening Ceremony.

The paper presents and discusses the pre-games residents' perceptions and expectations regarding the themes and content of the Opening Ceremony of the London 2012 Olympic Games. It focuses on residents' imagined ceremonial elements that would best represent and reflect British culture. In addition, the paper explores the meaning of 'Britishness' from the residents' perspective and how national identity can be best showcased in the Opening Ceremony of the London 2012 Games.

The article therefore aims to understand British residents' perceptions of the concept of 'Britishness' before the 2012 Olympic Games. Accordingly, the study's research questions (RQs) are the following: RQ1: What is the meaning of Britain's contemporary cultural identity? RQ2: What are the main components of Britishness? RQ3: What should be considered to be main elements of the London 2012 Opening Ceremony for the cultural 
representation? Specifically, this study targeted London residents from the Greenwich area because of its geographical proximity to the Olympic park. The paper presents and discusses the findings of this study and compares them with the actual Opening Ceremony of the London 2012 Olympic Games. It is of empirical importance to review the ideal of the Games' Opening Ceremony and the factual representation of the performance constructed by Olympic Delivery Authority (ODA) and the London Olympic Games Organising Committee (LOGOC).

\section{Literature Review}

\section{Olympic ceremonies and national identity}

Olympic ceremonies are based on a protocol specified by the Olympic Charter and also an artistic program, which is meant to present the culture of a host city/nation (Traganou, 2010). In addition, to express the distinctive elements of the Olympic Charter of universal ideals of humanism and peaceful internationalism, host nations are encouraged to take the opportunity to express the countries' unique characteristics and promote their national identities. The Olympic ceremonies and especially the opening one become 'condensers' of a nation's expectations, and their reception by the international audiences functions as a barometer that indicates the acceptance of the nation per se by its various others (Traganou, 2010).

Pujik (1999) commented that most countries want to create a performance which accurately represents the specific culture of that country. It should be noted that culture is a complex and dynamic concept. Culture refers to the characteristics of a particular country and it includes language, religion, cuisine, music and arts as well as the values and norms of the country's population (Edgar \& Sedgwick, 2005). Hence, representing a country's culture in an Olympic Games Opening Ceremony involves identifying those national cultural elements that are 
generally accepted as such by the nation and presenting them for an international audience in a digestible way (Pujik, 1999).

Opening Ceremonies should reflect the 'narratives of nation' showing inclusive agendas for the people of the nation (Hall, 1992). A host nation looks for recognition by the international community and at the same time seeks celebration of its own identity. 'Identity' is a term that is used to define a collection of central and tenacious attributes that shape an individual and define them profoundly (Parekh, 2000). 'National identity' is therefore a set of features and relationships that are constitutive of a nation and define and distinguish it from other nations. National identity emerged as a term in the 1950s when it replaced other terms such as 'national character', 'national soul' and 'national genius' (Parekh, 2003). National identity is not a static entity, as it is constantly negotiated and reformulated (Traganou, 2010; Kumar, 2003).

The complexities of various dimensions of identity are well documented in several studies (Gupta \& Ferguson, 1992; Hogan, 2003; Knauer \& Murray, 2000; Hinch \& Higham, 2004). It is also taken for granted that each country embodies its own distinctive culture and society. The terms "society" and "culture" are routinely simply appended to the names of nationstates, as when a tourist visits India to understand "Indian culture" and "Indian society" or Thailand to experience "Thai culture" or the United States to get a whiff of "American culture" (Gupta \& Ferguson, 1992).

Hogan (2003), sees the Olympic Games as "key sites in the discursive construction of nation" and their ceremonies as "major representations that constitute discourses of national identity, that is a set of stories, images, landscapes, scenarios, historical events, national symbols and 
rituals which stand for, and represent, the shared experiences, sorrows, triumphs and disasters which give meaning to the nation". The Olympic Games have been categorised as a "fine arts' programme as this mega sport event associates culture, identity and place with sporting events, while it also includes many major components of the nation (host community), such as history, tradition, image and values (Knauer \& Murray, 2000). Hinch and Higham (2004) indicated that the Opening and Closing Ceremonies of the Olympic Games provide a good example of the conscious mix of sport and culture. The performance that showcases 'national identity' and cultural values may also inspire tourists to visit the host nation (Morgan \& Prithchard, 2004). The Department of Culture, Media and Sport (DCMS) stated that the strategic plan for the 2012 London Olympic Games was not only to show the sporting capabilities of the nation and the regeneration of East London, but also to encourage new market tourists, either domestic or international, to visit London. They continued by adding: 'It is believed that by developing a concise national identity, the targets of hosting the Olympic Games can be achieved' (DCMS, 2007). With Britain's collective pasts and histories of immigration, the nation represents a distinctive heterogeneous population. Thus, a cultural representation of the diverse ethnic groups within the UK is deemed as a complex task.

\section{Multiculturalism in Modern Britain}

'Multiculturalism' assumes the co-existence of diverse cultures and is often manifested in ethnic and racial groups' social behaviours and values, patterns of thinking and communication styles (Werbner, 2013). Multiculturalism is both a feeble acknowledgment of the fact that cultures have lost their moorings in definite places and an attempt to subsume this plurality of cultures within the framework of a national identity (Gupta \& Ferguson, 1992). Multiculturalism or 'multicultural society' are used as indicators of social change to 
the "shifting ethnic composition of the population, an allegedly homogenous population has become heterogenous" (Heckman, 1993).

Britain has a long tradition of accommodating immigrants and refugees as it is part of a multiracial Commonwealth that contains a diversity of people (HMSO, 1991). In London, students and business people from overseas add to the numbers of nationalities already resident there and the city is among one of the most multiracial in the world. It has been estimated that some 160 languages and dialects are spoken by children in London schools. Dating back to the $16^{\text {th }}$ century, black immigrants were brought into Britain as domestic servants. In the $17^{\text {th }}$ and $18^{\text {th }}$ century, slaves from the Caribbean followed and black seamen traditionally settled in ports such as Liverpool, Bristol and Cardiff. Substantial immigration from the Caribbean, India, Pakistan and Bangladesh began in the 1950s. Chinese immigration began before World War II and accelerated in the 1960s. In 1972, Britain admitted some 28,000 Asians expelled from Uganda and in the late 1970s some 18,000 refugees from southeast Asia. Significant numbers of Italians, Greeks, Cypriots, Australians, New Zealanders and from the United States and Canada are now resident in Britain (HMSO, 1991).

Culture in modern Britain encompasses a range of diverse and minority cultures. According to Jacobson (1997) in multicultural British society, its identity i.e. Britishness involves more than one set of boundaries. Three main boundaries of Britishness have been identified: civic boundary, racial boundary and cultural boundary. Each of these boundaries defines people from a different perspective of being British (Jacobson, 1997). More importantly, British cultural identity comprises people from more than four distinct states i.e. England, Scotland, Wales and Northern Ireland. According to Knauer and Murray (2000), in the representation of 'Britishness' the input of English element is more emphasised since Britain has been 
primarily an England dominated country. However, it should be noted that, British cultural identity also comprises social and economic post-war immigrants from the Caribbean, Africa, India, China and Pakistan and other minority ethnic groups (Kumar, 2003). More recently, an influx of people from Poland and other eastern European countries has settled into Britain (Owen, 2002) due to European Union membership. As a result, these 'imported cultures' i.e. immigrants who brought their culture and lifestyle into Britain have made great impacts on the modern British society, have influenced and transformed the essence of Britishness contributing to its complexity (Storry \& Childs, 1997). The existing cultural diversity entails a considerable influence on socio-cultural intermingling.

The intricacies of multiculturalism in contemporary Britain and the mythopoeia of multiethnic Britain are well documented in several studies (Falcous \& Silk, 2010; Back et al., 2012; Manley \& Silk, 2014). The perception of Britishness differs considerably depending on the demographic characteristics of different regional residents. This view was endorsed by Arts Council England (2009). The London 2012 Olympic Games offered a unique opportunity for the UK to reinforce the country's reputation as a world leader in multiculturalism (Arts Council England, 2009). The discourse of multiculturalism is found in several studies (e.g. Fortier 2005; Back et al., 2012; Silk, 2014; Manley \& Silk, 2014).

The importance of representing aspects of British multiculturalism during the Opening Ceremony of the London 2012 Games was also supported by the DCMS (2007). It was argued that the Games would provide a vibrant environment where individuals and multicultural communities could express their creativity and imagination in the arts, highlighting cultural diversity in the United Kingdom (Arts Council England, 2009). It was suggested that during the planning of the Olympic Games in London, the participation of 
England, Scotland, Wales, Northern Ireland and ethnic communities would enhance their working relationships within the United Kingdom (DCMS, 2007). Other benefits of showcasing the British cultural identity during the Games included enhancing London's touristic image and reinforcing economic and business investment (Hall, 1992).

\section{Methodology}

As the study aims to address three research questions RQ1, RQ2 and RQ3, the understanding of UK residents' knowledge and perception of Britishness is of importance as it assists in knowing what public in the UK perceived as the main elements to be included in the opening ceremony of the London 2012 Games. To fulfil research objectives of this paper, a mix of research methods was applied. Quantitative and qualitative research methods were adopted to ensure the breadth and depth were captured in this study. Furthermore, the use of qualitative research method in the form of in-depth interview is often used to understand the research context and clarity in defining the research problem (Myers, 2009). It is evident that qualitative research methods provide richness, depth and flexibility (Deery, 2012). Xin et al., (2013) also commented on the use of qualitative research with regard to its advantage of developing themes and models which help to conceptualise a research study. While qualitative methods provide such benefits to research, it often however is used to inform quantitative research where patterns, associations and perspectives are identified (Williams et al., 2014). In other words, quantitative research, which is generated through the findings of qualitative research design assists in increasing the validity of the study significantly (Gray, 2009).

The study was conducted in two phases, questionnaire survey and in-depth interview. The form of a questionnaire was purposely adopted to determine the views and opinions of British 
residents (Morrow et al., 2005). Due to the nature of this study and its research aim, a nonprobability sampling was used. It is argued that in order to explore the meaning and elements of British identity and Britishness, purposive sampling strategy was the most appropriate technique to be employed. Inclusion criteria for completion of the questionnaire by respondents comprised age (18 years old and over), British citizens or participants who held UK residency (5 years and over; UK Government, 2016).

\section{Questionnaire design}

The design of the survey questionnaire was based on the steps proposed by Thomas and Nelson (2001) and Morrow et al., (2005) for conducting survey research. First, the research questions were determined (i.e. purpose identified and variables to be observed were listed). Second, the type of sampling and sample size were identified. Third, the questionnaire was constructed to include questions relevant to the topic of investigation. Fourth, a pilot study was carried out in order to identify and define the themes that were used in the survey. This pilot study involved one-to-one interviews with a small number of British residents. Twenty British residents were selected to be the sample population for the qualitative research. The in-depth interviews aimed to extract research themes for the quantitative stage of the study. Although 20 survey interviewees may be considered a small sample, this article does not aim to produce general representativeness (Silverman, 1993). When applying qualitative sampling to extract research themes, theoretical saturation of information was used as a guide to determine the quantity of data to be used (Boddy, 2016). This quantity of data was achieved with 20 interviews since no further contributions were made.

The first stage of the research took place in High Wycombe, Buckinghamshire, UK. The sample sites in High Wycombe were the local theatre (Wycombe Swan) and the local sports 
centre (Handy Cross). The reasons for selecting these two sites for pilot work were that they were frequented by British residents who were interested in cultural events (theatrical plays and other types of performances) or were involved in physical activity and exercise (sport participation and awareness of the Olympics). By using these locations, the researchers anticipated that they were more likely to interview those individuals who were culturally aware and engaged in sporting activities.

The interviews were analysed using thematic analysis and the emerging themes were used to formulate the survey questionnaire. This study demonstrates that use of thematic analysis was particularly useful as it creates and identifies reoccurring themes around a specific topic in the data but also develops a framework of themes that assists in interpreting findings (Flick, 2002). Five ceremonial elements were identified as important for inclusion in the Opening Ceremony of the 2012 Olympic Games and three elements surrounding British culture were identified from this fieldwork. Finally, a questionnaire was constructed and administered to the study population. The type of questionnaire used in this study was a self-administered questionnaire. During fieldwork the majority of completed questionnaires were collected on site. Descriptive statistics were used to identify the number of residents' order of preference towards the key elements.

The questionnaire comprised three sections. The first section included demographic questions about the respondents' age, gender, occupation and length of residency in the UK. The second section included questions on different presentation elements for the opening ceremony of the London 2012 Olympic Games. The respondents' views were assessed on five ceremonial elements that included: London's iconic attractions, British culture and 
tradition, ethnic minority cultures, pop music culture, and modern Britain and British history. These elements were identified by interviewees at the initial stage of this research

The third section of the survey questionnaire included closed-ended questions on the meaning of British culture and Britishness that were also rated on a 5-point Likert scale ranging from 1='strongly agree', 2='agree', 3='neutral', 4='disagree', 5='strongly disagree' with an extra category $6=$ 'do not care' to allow participants to express their indifference. This extra category emerged from the pilot study. The second and third sections also included openended questions. The inclusion of open-ended questions was to provide respondents with the opportunity to express their opinions and views, which enriched the data. As Miles and Huberman (1994) point out, qualitative data can benefit the analysis of quantitative data by 'validating, interpreting, clarifying, and illustrating quantitative findings'. Furthermore, the quantitative data allowed the possibility of 'conceptual mapping' of the issues to be addressed (Bryman, 1988).

\section{Questionnaire reliability and validity}

To ensure reliability of the survey questionnaire items the researchers conducted a second pilot study whereby they administered the questionnaire to a small group of respondents (at the same location) on two occasions spaced three weeks apart (Morrow et al., 2005). Minor adjustments were undertaken to the questionnaire. The validity of the questionnaire was also assessed through asking the pilot respondents to check the wording of the questions for any bias or lack of clarity. This was done to eliminate the possibility of respondents misinterpreting the questions (Thomas \& Nelson, 2001). The purpose of the study was 
explained to all respondents and they were reassured that their responses would remain anonymous.

\section{Data collection and study area}

Fieldwork took place over the months of January and February 2011, some seventeen months prior to the performance and broadcast of the London 2012 Olympic Games Opening Ceremony on $27^{\text {th }}$ of July 2012. In total, three hundred and one residents (male: $n=135$, female: $n=166$ ) were surveyed in Greenwich town centre and its surrounding areas. The area of Greenwich (see Diagram 1) was selected for undertaking fieldwork for the following reasons. Firstly, Greenwich was one of the major host venues for the 2012 Olympics and thus it seems to have had a great opportunity to benefit from tourist facilities and attractions. According to Greenwich Council (2009), one of the economic benefits would be an increase in tourism. Secondly, the 2012 London Games offers a great opportunity for Greenwich to generate a positive image and reputation as a high quality visitor destination. It was therefore anticipated that due to the impact of the Olympic Games, the residents of Greenwich would have a high degree of awareness and interest in contributing their views and perceptions of presentational elements in the opening ceremony of the London 2012 Olympic Games and the meaning of British culture. In hindsight, inclusion of respondents from other regions of London would have enhanced the study findings. 


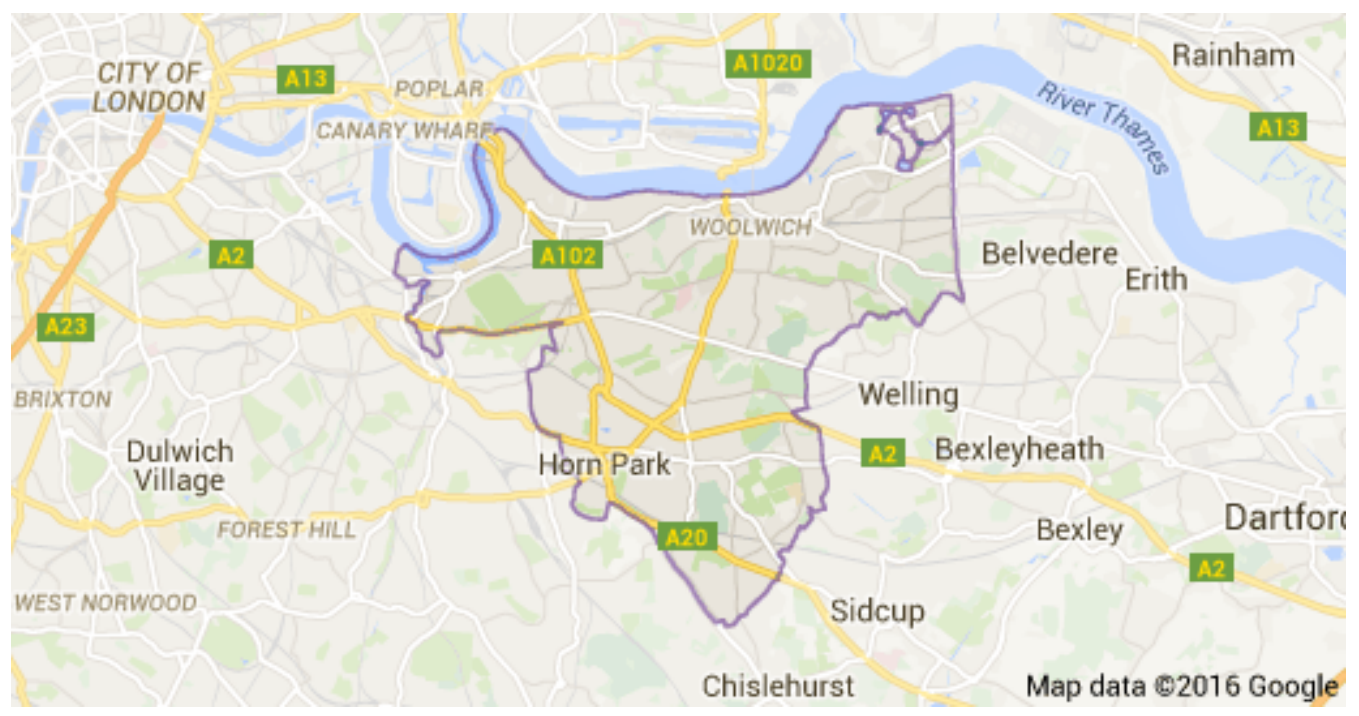

Diagram 1. The outlined area shows the Royal Borough of Greenwich, Greater London in relation to the River Thames and the City of London. From: www.googlemaps.co.uk

\section{Data analysis}

Data was analysed using two methods. First, the closed-ended and Likert scale responses were analysed for frequencies and percentages using Excel version 13.0. Second, thematic analysis was employed to analyse statements and sentences from the open-ended questions and cluster them into common themes as described by Biddle et al., (2001). The frequency count of each response on the Likert scale for every question was calculated and converted into a percentage. The responses for 'strongly agree' and 'agree' were pulled together to identify collective agreement with the theme in question. The responses for 'strongly disagree' and 'disagree' were also pulled together to identify the degree of disagreement. There were also 'neutral' and 'do not care' responses that were assessed for their frequency count and percentage. 


\section{Results and Discussion}

\section{Demographic profile of respondents}

The demographic profile of the study respondents is shown in Table 1. All respondents had been living in Britain for 16 years or more. The majority of respondents recognised themselves as British and the rest of the respondents identified themselves as English (as opposed to British), European or Asian. In terms of gender, there were 24 more males compared to females. An equal amount of young and older respondents was surveyed (18-35 years: $51.2 \%$ and 36 years or above: $48.8 \%$ ). With regard to the occupational status, a large proportion of respondents were in professional and managerial employment, followed by one quarter of respondents employed in non-manual and clerical positions, whereas fewer respondents were students, retired or unemployed and manual workers. It should be noted that the number of manual workers surveyed was only $3.3 \%$, which was a limitation of this study as this particular community group was under-represented in this research. It should be noted that the sample was male dominated and hence, female perceptions may be seen as being under-represented. Also, there were more respondents in professional and managerial employment and this might be viewed as an under-representation of people in other occupations.

Views of the presentational elements in the opening ceremony

Five presentational elements were examined in order to understand the degree of importance in including them in the London 2012 Olympic Games opening ceremony (1=strongly agree, $2=$ agree, $3=$ neutral, $4=$ disagree, $5=$ strongly disagree and $6=$ do not care). Figure 1 shows the residents' perceived importance of each of the five selected elements that were proposed to them for inclusion in the Opening Ceremony of the 2012 Olympic Games. The specific responses to each element can be seen in Table 1. 
Table 1. Demographic characteristics of respondents $(n=301)$.

\begin{tabular}{llcc}
\hline Variable & Description & Frequency (n) & Percentage (\%) \\
\hline National identity & British & 235 & 78.4 \\
& English, Asian, European & 66 & 21.9 \\
Age (yrs) & $18-35$ & 154 & 51.0 \\
& 36 and over & 147 & 49.0 \\
Length of UK residence (yrs) & 16 and over & 301 & 100 \\
Gender & Male & 174 & 57.8 \\
& Female & 127 & 42.2 \\
& Professional / managerial & 119 & 39.5 \\
Profession & Non manual/clerical & 93 & 31.0 \\
& Student & 48 & 15.9 \\
& Retired/unemployed & 31 & 3.3 \\
& Manual worker & 10 & 10.3 \\
& & &
\end{tabular}

The findings of this study showed that 'London's iconic attractions' and 'British culture and traditions' were recognised as the most important element for inclusion in the Opening Ceremony followed by 'Modern Britain and Britain's history' with 'Pop culture' and 'ethnic minorities culture' in the fourth and fifth places, respectively. 'London's iconic attractions' was identified as the most important element by $74.4 \%$ of respondents (see Table 2). It appears that respondents have very strong views about what they would have liked to see in the Opening Ceremony of the Olympic Games. However, what the study's respondents seem to have had in mind were attractions such as the Big Ben, Buckingham Palace and River Thames amongst others, as these were the prominent answers respondents provided in the 
open-ended survey questions. In the Opening Ceremony designed by film director, Danny Boyle-most known for his adaptations of Trainspotting and Slumdog Millionaire (Manley and Silk, 2014), iconic attractions included well known 'iconic personalities' such as footballer David Beckham in a speed boat cruising along the River Thames and fictional character James Bond played by actor Daniel Craig visiting Her Majesty the Queen inside Buckingham Palace (Visit London, 2012). This representation of London's iconic attractions did not quite match the views of the study's respondents. Fieldwork showed that iconic attractions are those places and/or buildings that tourists identify with the host city of London e.g Big Ben, Tate Modern Gallery, Tower Bridge, London Eye, Covent Garden, Piccadilly Circus, St Paul's Cathedral, Westminster Abbey and Houses of Parliament to name a few. Admittedly, David Beckham, Sherlock Holmes and the Queen are the 'human icons of London' in a similar manner that Big Ben and London Eye are 'landmark icons of London'. One might argue that framing these iconic personalities with London's landmarks was a successful combination and a very effective way to publicise both icons on a global stage. Nevertheless, it is not possible to know whether the study's respondents were satisfied by the inclusion of iconic personalities alongside London's landmarks as a qualitative investigation of how respondents would like to see London's landmarks 'performed' in the Opening Ceremony did not occur in this study. 
'British culture and traditions' was the second most important element for inclusion in the Opening Ceremony identified by $74.2 \%$ of respondents. British residents were very specific about the elements they wished to see included for this ceremonial element. Some of the qualitative responses accompanying this theme included: 'things that represent British character and psyche', 'displays highlighting British history and culture', 'British life', 'brass bands, Morris dancing, maypoles, beefeaters'. To some extent these imagined themes were represented in the actual ceremony. Its artistic director, Danny Boyle, said the theme of the Opening Ceremony was "this is for everyone" and it included sequences about the National Health Service, with one showing menacing figures from children's literature looming over children in hospital beds (BBC News, 2012). The scene for the opening sequence of Danny Boyle's $£ 27 \mathrm{~m}$ Opening Ceremony extravaganza included a surreal vista of a "green and pleasant land", with giant maypoles representing the symbols of the four nations of the UK around which children danced (Gibson, 2012). This performance illustrates the reflection of religious practice and lifestyle in good old days Britain allowing the nostalgic image of children dancing around the maypole to be promoted for tourism (Dann, 1998).

Brass bands were included in the Opening Ceremony with the London Symphony Orchestra, the oldest of London's symphony orchestras founded in 1904 giving a live performance. The density of British literary brilliance also featured in the spectacle from its outset including Shakespeare, Blake, Tolkein, Ian Flemming (a double hit with James Bond and Chitty Chitty Bang Bang) and also Carroll, JK Rowling and Barrie (Higgins, 2012).

On the other hand, even though a Beefeater was chosen to carry the Olympic torch at the Tower of London on the $20^{\text {th }}$ of July 2012, where it stayed until the evening of the Opening 
Ceremony (Associated Press, 2012), there was an irreverent wit to eschew Beefeaters at the Opening Ceremony (Morra, 2013; p. 17). The Yeomen Warders of Her Majesty's Royal Palace and Fortress of the Tower of London, and Members of the Sovereign's Body Guard of the Yeoman Guard Extraordinary, popularly known as Beefeaters, are ceremonial guardians of the Tower of London. In principle they are responsible for looking after any prisoners in the Tower and safeguarding the British crown jewels, but in practice they act as tour guides and are a tourist attraction in their own right (Tickle, 2011). The name Beefeater is more likely to have originated from the time when the Yeomen Warders at the Tower were paid part of their salary with chunks of beef, a practice that took place right up until the 1800s (Tickle, 2011). Arguably, the Beefeaters are an integral part of British culture and tradition as it has evolved through the past three centuries.

Different from what was identified in this research, Morris dancing was ignored for inclusion in the Opening Ceremony although it showcases traditional English folk dance which usually accompanied by music that is based on rhythmic stepping and the execution of choreographed figures by a group of dancers, usually wearing bell pads on their shins (Heany, 2004). There is no doubt that Morris dancing has been one of the cultural traditions of the nation for the past few centuries. News of non-inclusion of Morris dancing in the Opening Ceremony led the Association of Morris dancers to launch an electronic petition in the year prior to the Olympic Games (see http://epetitions.direct.gov.uk/petitions/25621). This electronic petition did not materialise due to Her Majesty's Government not supporting freedom of information requests and considering the matter as a responsibility of the London Organising Committee for the Olympic Games (LOCOG). On the electronic petition, LOCOG stated that 'the Olympic ceremonies team are working hard to scope the ambition of the ceremonies. As part of this process they will consider a range of options which reflect 
and celebrate our unique British values and culture'. The message ended with a request to contact LOCOG via various routes to support the inclusion of Morris dancing as representative of English cultural tradition that deserves a show to the world. Eventually, Morris dancing was not included in the Opening Ceremony, but, due to popular demand, the group 'Rag Morris' was selected to perform in the Closing Ceremony (University of Bristol, 2012).

The third most important element to be included in the Opening Ceremony of London 2012 Games was 'Modern Britain and Britain's history' identified by $63.3 \%$ of respondents. Some of the respondents' qualitative responses under this theme included: 'what we have given the world, i.e. inventions', 'all past British Olympians on parade', 'something new, the "wow" factor' and 'pearly kings and queens'. It is interesting to see that this view was, to some extent, shared by film director, Danny Boyle, who explained that the aim of the Opening Ceremony was to incorporate 'where were we, [Britain] have come from', 'where we are now', 'where we are going', 'and on that journey, what are the values that we hold up as being valuable' (Boyle, 2012). British historical elements and modern Britain were represented in the 'Isles of Wonder', the theme name of the Opening Ceremony. The ceremony began with bucolic Britain, a (past) place centred on the Wind in the Willows and the countryside "we all believe existed once" (LOCOG, 2012). It continued with Isambard Kingdom Brunel overseeing the dismantling of the meadows and fields that were replaced by signifiers of the industrial age including vast smoking chimneys, steam engines and spinning jennys, culminating in the forging of the Olympic rings (Manley and Silk, 2014). Boyle also contemplated the gendered, raced, and classed problems that arose in Britain during the industrial revolution and how they were solved through the abilities of working suffragettes, trade unionists, descendants of the Windrush, Pearly Kings and Queens, Chelsea pensioners and a squadron of Sgt. Pepper's era Beatles and inflatable yellow submarines (Manley and 
Silk, 2014). However, the contribution of English inventors and scientists was downplayed in the ceremony, even though it has been recognised that they have played a significant role in the development of science and engineering (Lindberg, 2007). With the exception of some glorious achievement such as Isambard Kingdom Brunel, the English mechanical and civil engineer who built dockyards, the Great Western Railway (Bindle, 2005) many prominent scientists such as Charles Darwin, Isaac Newton, Roger and Francis Bacon, and Alan Turing were not mentioned in the ceremony. Admittedly, there is an incredible amount of history and who is to decide which part of it is most important, but perhaps a short video coverage of the aforementioned scientists and inventors could have been included in the Opening Ceremony alongside live performances to coincide with Danny Boyle's ambition to show 'what Britain has given to the world'.

The fourth most important element for inclusion in the 2012 Olympic Games Opening Ceremony was 'Pop culture' identified by $38.2 \%$ of respondents. Qualitative responses included: 'British acts and artists', 'dancing, acrobatics, big bands', 'youth acts and fireworks'. Boyle ensured that popular music featured throughout the Opening Ceremony connected the past to a vision of the present and future and included pop icons such as Mike Oldfield performing 'Tubular Bells' and, rising urban star Emili Sandé singing 'Abide With Me' (the hymn traditionally sung at many UK sporting occasions, in a section dedicated to the victims of the London $7 / 7$ bombings, which happened the day after London was announced as the 2012 Olympic Games host city in 2005). To end the evening Sir Paul McCartney sung 'Hey Jude'(Boyle, 2012) a song that often ends a night out in Britain (Miah, 2012). The Opening Ceremony of the London 2012 Olympics was essentially a pageant of British pop, tracing a national pop cultural history from The Beatles to Dizzee Rascal's Bonkers (Adams, 2014). Participating artists included the Who, the Rolling Stones, the Beatles and the Kinks (from the 1960s), David Bowie, Queen, Mud, The Jam and the Sex 
Pistols (from the 1970s), New Order and Frankie Goes To Hollywood (from the 1980s), while the 1990s covered Britpop bands Blur and dance acts such as the Prodigy and Underworld, with dozens of dancers in day-glo costumes staging their own mini-rave (Sutherland, 2012). The representation of this ceremonial element was very pronounced in the actual ceremony however, it only featured as the fourth most important element for inclusion on the part of this study's respondents.

Finally, 'ethnic minority culture' was perceived as the least important element for inclusion in the Opening Ceremony with only $35.2 \%$ of the respondents choosing this theme. In the Isles of Wonder, Danny Boyle highlighted the social and cultural values of harmony, coexistence, diversity, integration and belonging within contemporary Britain (Manley and Silk, 2014). Multicultural Britain was depicted in a performance featuring Frankie (a mixed race male immigrant from Portugal) and June (a mixed ethnic background woman), a couple living in an 'ordinary British house' the kind in which most British people live (LOCOG, 2012: 30). The theme showcased a mixed-race family surrounded by 1,427 young volunteer dancers from a range of undefined racial and ethnic backgrounds (Manley and Silk, 2014). Higgins (2012) commented that Boyle's representation of Britain showed a tolerant, multicultural, fair and gay friendly country that holds the principles of the welfare state stoutly at its heart. 
Table 2. British residents' $(n=301)$ views of five selected presentation elements at the Opening Ceremony of the 2012 Olympic Games.

\section{Element}

\begin{tabular}{llllll}
\hline Response & $\begin{array}{l}\text { London's } \\
\text { iconic } \\
\text { attractions }\end{array}$ & $\begin{array}{l}\text { British } \\
\text { culture and } \\
\text { tradition }(\%)\end{array}$ & $\begin{array}{l}\text { Ethnic } \\
\text { minorities } \\
\text { culture }(\%)\end{array}$ & $\begin{array}{l}\text { Pop culture } \\
(\%)\end{array}$ & $\begin{array}{l}\text { Modern } \\
\text { Britain and }\end{array}$ \\
& & & & $\begin{array}{l}\text { Britain's } \\
\text { history (\%) }\end{array}$
\end{tabular}

\begin{tabular}{llllll}
\hline Strongly agree & 28.9 & 39.7 & 8.3 & 7.0 & 19.0 \\
Agree & 45.5 & 34.5 & 26.9 & 31.2 & 44.3 \\
Neutral & 13.6 & 19.6 & 38.5 & 28.9 & 25.3 \\
Disagree & 8.6 & 4.2 & 18.6 & 21.3 & 7.3 \\
$\begin{array}{l}\text { Strongly } \\
\text { disagree }\end{array}$ & 2.0 & 1.3 & 6.0 & 10.3 & 2.7 \\
Do not care & 1.4 & 0.7 & 1.7 & 1.3 & 1.4 \\
& & & & & \\
\hline
\end{tabular}

Views on Britishness

Respondents' perceptions of what is British culture are shown in Table 3. The table shows some interesting results with an overwhelming majority of respondents $(73.4 \%)$ agreeing that 'British culture exists', but in their own words stating that 'it is complex', 'dynamic', 'multicultural', 'unique and diverse', 'a culture that upholds traditions and history whilst recognising its changing face and transition to a multicultural environment' and 'fish and chips, red buses and stiff upper lip'. Nearly 60.0\% view contemporary British culture as comprising an amalgamation of British and ethnic minority cultures. Only $11.0 \%$ of respondents agreed that in the present day, there is actually no such a thing as British culture 
and $13.0 \%$ had no view on this statement. These findings suggest that respondents are aware of the influx of immigration into Britain and the issues associated with cultural intermingling which has been a growing concern for the country (Falcous \& Silk, 2010; Storry \& Childs, 1997). Formerly, a very homogenous society, since World War II, Britain has become increasingly diverse as it has accommodated large immigrant populations, particularly from its former colonies such as India, Pakistan and the West Indies. The mixture of ethnic groups and cultures make it difficult to define "Britishness" nowadays and a debate rages within the nation as to what now really constitutes being a Briton (Triandafyllidou, 2012). It should be noted that respondents showed a quite distinctive perception toward multiculturalism.

Multiculturalism is a complex and problematic term and it affects issues such as national and ethnic identities as well as values. Smyth (1994) commented that the national identity of modern Britain is a mix of national identity, ethnic identities and the emergence of new ways of being 'British'. The changing nature of Britain cannot be accounted for without a consideration of the transformations in social identity. According to Storry and Childs (1997), social identity is a highly complex and contentious concept. It can be defined as 'the patterns of behaviour, cultural values and political affiliations shared by certain individuals who come together to form a group within a larger population'. It appears that the cultural values of respondents have been shaped by the existence of multiculturalism in Britain today.

'Rich history and traditions' was selected by approximately $40.0 \%$ of the study's respondents as representative of British culture was also represented in Boyle's opening spectacle where he evoked a fantasy of a historical Britain reassuring the past that confirms and celebrates 'native Britishness' (Manley \& Silk, 2014). For instance, in the Opening Ceremony the industrial revolution and its social values were conjured through railway tracks and some 
steam heralding the dramatic changes in British society during the 'age of the machine'. The British 'love affair' with the National Health Service was also represented in the artistic display showing a dance by patients, nurses and doctors around an illuminated NHS sign as well as the literary heritage i.e. storytelling of children's novels, such as Harry Potter and Peter Pan.

Table 3. British residents' $(n=301)$ views on themes proposed to define British culture.

Theme

\begin{tabular}{llll}
\hline Response & \multicolumn{2}{l}{ There is no such thing } \\
& $\begin{array}{l}\text { as British culture } \\
(\%)\end{array}$ & $\begin{array}{l}\text { Prestige, rich history } \\
\text { and traditions of Britain }\end{array}$ & $\begin{array}{l}\text { Accommodating British } \\
\text { and ethnic minorities' } \\
\text { cultures (\%) }\end{array}$ \\
\hline Strongly agree & 2.7 & 7.6 & 12.3 \\
Agree & 8.3 & 31.6 & 47.5 \\
Neutral & 13.0 & 25.6 & 20.9 \\
Disagree & 42.2 & 24.3 & 14.6 \\
Strongly & 31.2 & 9.6 & 4.3 \\
disagree & & & 0.3 \\
Do not care & 0.3 & 1.3 & \\
& & & \\
\hline
\end{tabular}

\section{Concluding points}

Mega sport events, such as the Olympic Games, have been used as a promotional tool for enhancing a destination's cultural image (Kaplanidou, 2006). The Opening Ceremony of the Olympic Games is said to raise awareness of the major tourist attractions of the host destination (Sealy and Wickens, 2008). As a special event it should show the uniqueness of the city where the Games are taking place and their most culturally significant landmarks. An 
interesting finding was that respondents identified London's iconic attractions, such as the Big Ben and Buckingham Palace, as the most important elements for inclusion in the imagined Opening Ceremony. In the actual ceremony, representations of iconic landmarks were however, framed with 'iconic' personalities, such as footballer David Beckham, that have gained iconic status due to media exposure. This raises questions as to whether the Opening Ceremony acted as a tourism promotional tool for both domestic and international prospective visitors as originally envisaged by the UK Government (DCMS, 2007). A published statement about the potential tourism revenue generated by the 2012 Olympic Games Opening Ceremony stated: 'The media attention that went along with London 2012, from the Olympic Opening Ceremony to the Paralympic Closing Ceremony, showed the world all the attractions that make Britain an amazing place to visit' (DCMS, 2013). Based on this premise, the UK Government launched the 'GREAT Campaign' to 'extend the economic potential of London 2012 by promoting the things that make Britain outstanding. The themes of the campaign are: countryside, culture, heritage, creativity, entrepreneurs, green, innovation, knowledge, shopping, sport, music and technology. One of the campaign's main objectives is to increase the number of tourists visiting the UK. We have so far provided 'Visit Britain' with over $£ 22$ million to run their part of the GREAT campaign until at least 2015' (DCMS, 2013). However, further research needs to be undertaken to ascertain the appeal to international visitors of London's iconic personalities alongside iconic built attractions.

Other important presentational elements as identified by respondents i.e. 'British culture and tradition', 'Modern Britain and Britain's history' and 'Pop culture' were all themes that were represented in Boyle's opening spectacle. With the exception of Beefeaters and Morris dancing that did not feature in the Opening Ceremony, this finding shows that the imagined 
views of local residents were, to some extent, represented in the actual 2012 Olympic Games Opening Ceremony. It might be argued by the Opening Ceremony's Oscar-winning film director, Danny Boyle, that it is not possible to accommodate every single theme suggested by local residents into the actual spectacle. However, it has been reported that 'the domestic reception of the Olympic ceremonies is not monolithic; internal differences about the idea of nation surface and become points of debate after the ceremonies take place and in the postOlympic period' (Traganou, 2010). Residents' perceptions of themes to be included in the opening spectacle of the Olympic Games are of paramount importance. A striking example is that despite the fact that Morris dance is identified as one of the important ceremonial element which represents British culture and tradition, the failure of Morris dance performance inclusion during the Opening Ceremony of the London 2012 caused indignation among Morris dance groups and public debate. The magnitude of ire was such that Member of Parliament, Sir John Russell, raised the issue at the House of Commons on $23^{\text {rd }}$ February 2012 questioning the exclusion of Morris dancing, 'a traditional folk culture of the nation and its regions' as he called it, from the Opening Ceremony (Daily Gazette, 2012). Therefore, it does matter that residents' perceptions of what should be included in the Opening Ceremony are, by and large, met.

Cultural diversity and traditional British elements were also emphasised by the study's respondents surveyed in the Greenwich area. Respondents agreed that 'British culture' exists in contemporary Britain, however their perception of the meaning of 'Britishness' seems to be more complex and dynamic. In their own words they interpreted Britishness as 'an amalgamation of British culture and ethnic minority cultures'. The study findings might be of use to scholars and other mega-event organising committees who wish to use them in the planning of Olympic and other sport event ceremonial presentations. This paper has only 
considered the Opening Ceremony because arguably this is the most prominent display with the greatest financial and creative investment, but it acknowledges the importance of the Closing Ceremony. Hence, research should also be carried out on the Closing Ceremony, an equally important event for showcasing cultural identity and iconic attractions.

\section{Research limitations and contributions}

One of the limitations is that the cultural identity elements are unique to the UK. Secondly, this paper does not aim to provide a comprehensive overview of cultural representation of the ever increasing popular theme of Olympic Games ceremonies. Thirdly, the research did not involve a diverse group of stakeholders who could have also expressed their views on the meaning of Britishness. Furthermore, the time period of fieldwork was not conducive to yielding rich qualitative data, as it was conducted in the chilling winter months of January and February where respondents' contributions may have been affected by being surveyed outdoors. However, due to budget and time limitations further fieldwork could not be undertaken. This confounding variable has impacted the size of the survey sample and hence, the study does not make claims to producing general representativeness (see Silverman, 1993).

Even though the authors recognise these limitations, the findings of this study are valid until 'further notice' (Sealy \& Wickens, 2008) i.e. until another researcher carries out a similar study with similar aims and objectives and confirms or disputes its findings. Main contributions of this paper include: it provides a platform for further research in debating and researching cultural identity; highlights the gap between residents' perceptions and actual implementation of ceremonial elements in the London 2012 Olympic Games; projects the voice of the neglected stakeholder group, 'the locals', to a wider audience. 


\section{References}

Adams, R. (2014). Book review: Britishness, popular music and national identity by Irene Morra. Available from: http://blogs.lse.ac.uk/lsereviewofbooks/2014/04/13/book-reviewbritishness-popular-music-and-national-identity/

Arning, C. (2013). Soft Power, Ideology and Symbolic Manipulation in Summer Olympic Games Opening Ceremonies: A Semiotic Analysis. Social Semiotics, 23(4): 523-544.

Arts Council England (2009). 2012 Games. Our vision. The cultural Olympiad and beyond. $\begin{array}{lllll}\text { Accessed } & 15^{\text {th }} & \text { February } & 2009 . & \text { Available }\end{array}$ http://www.artscouncil.org.uk/downloads/2012_games_ourvision.pdf

Associated Press (2012). A beefeater carries the Olympic torch to the Tower of London on July 2012 . 20 th $\quad$ Available from: https://uk.eurosport.yahoo.com/20072012/5/photo/20072012205544.html

Back, L., Sinha, S., Bryan, C. (2012). New hierarchies of belonging. European Journal of Cultural Studies, 15(2): 139-154.

Barcelona Olímpica (1992). Ceremonies. Reference documents. Available from: $\underline{\text { www.barcelonaolimpica.net }}$

Brindle, S. (2005). Brunel: The Man Who Built the World. Weidenfield \& Nicholson. p. 28.

Boddy, C.R. (2016). Sample size for qualitative research. Qualitative Market Research: An International Journal, 19(4): 1-7.

Boyle, D. (2012). Boyle Reveals Opening Ceremony. The Daily Telegraph. June 12, 2012. Available from: 
http://www.telegraph.co.uk/sport/olympics/olympicsvideo/9326706/London-2012-

Olympics-Opening-Ceremony-details-revealed.html

British Broadcasting Corporation (BBC; 2004). Olympics open in Athens. The $28^{\text {th }}$ Olympic Games have began in a lavish style in Athens. Available from: http://news.bbc.co.uk/sport1/hi/olympics_2004/3557922.stm

BBC News (2012). London 2012: Boris Johnson dismisses 'leftie' complaint. $28^{\text {th }}$ July, 2012. Available from: http://www.bbc.co.uk/news/uk-19029510

Boddy, C.R. (2016). "Sample size for qualitative research". Qualitative Market Research: An International Journal, 19(4): 1-7.

Biddle, S., Markland, D., Gilbourne, D., Chatzissarantis, N., Sparkes, A. (2001). Research methods in sport and exercise psychology: quantitative and qualitative issues. Journal of Sports Sciences, 19: 777-809.

Bryman, A. (1988). Quatity and quality in social research. London:Routledge.

Chatziefstathiou, D. (2005). The changing nature of the ideology of Olympism in the modern Olympic era. $\mathrm{PhD}$ Thesis. Loughborough University repository. Available from: https://dspace.lboro.ac.uk/2134/2820

Deery, M., Jago, L., Fredline, L. (2012). Rethinking social impacts of tourism research: A new research agenda. Tourism Management, 33: 64-73

Cook, I., Miles, S. (2010). Beijing 2008. In: Gold, J. and Gold, M., (Eds.) Olympic cities: city agendas, planning and the world games, 1896-2012, London: Routledge. pp. 340-358.

Daily Gazette (2012). Sir Bob asks 'why no folk' at Olympics? 23 ${ }^{\text {rd }}$ February 2012. Available from:http://www.gazettenews.co.uk/news/local/colchester/9551346.Sir_Bob_asks_why_no_folk_at_Olympics $\underline{\mathrm{r} / \text { ? ref }=\mathrm{rss}}$ 
Dann, G (1998). 'There is no business like old business': tourism, the nostalgia industry of the future. In Theobald, W.F. (Eds.), Global Tourism. Oxford: Butterworth-Heinemann, pp.29-43.

Department for Culture, Media and Sport (DCMS). (2007). Winning: a tourism strategy for 2012 and beyond. Executive summary. VisitBritain and Visit London.

DCMS (2013). Policy: helping the UK tourism industry to grow. UK economy. $27^{\text {th }}$ February 2013. Available from: https://www.gov.uk/government/policies/helping-the-uk-tourismindustry-to-grow

Edgar, A., Sedgwick, P. (2005). Cultural theory: the key concepts. $2^{\text {nd }}$ edition, NY: Routledge.

Falcous, M., Silk, M.L. (2010). Olympic bidding, multicultural nationalism, terror, and the epistemological violence of 'making Britain proud. Studies in Ethnicity and Nationalism, 10(2): 167-186.

Flick, U. (2002) 'Qualitative research-state of the art.' Social Science Information, 41(1): 524.

Fortier, A.M. (2005). Pride politics and multiculturalist citizenship. Ethnic and Racial Studies, 28(3): 559-578.

Gray, D. E. (2009). Doing research in the real world. London: SAGE

Gupta A., Ferguson J, (1992). Beyond "culture": space, identity and the politics of difference. Cultural Anthropology, 7(1): 6-23.

Greenwich Council (2009). Tourism opportunities. Accessed $15^{\text {th }}$ March 2009. Available from: http://www.greenwich.gov.uk/Greenwich/2012Games/TourismOpportunities.htm

Hall, C.M. (1992). Hallmark tourist events: impacts, management and planning. UK: Belhaven. 
Hall, S. (1992). The question of cultural identity. In: S. Hall, D. Held, \& T. McGrew (Eds.), Modernity and its futures. Cambridge, UK: Polity, pp. 273-325.

Heaney, M. (2004). The earliest reference to the Morris Dance? Folk Music Journal, 8(4): $513-515$

Her Majesty's Stationary Office (1991). Aspects of Britain: ethnic minorities. London: HMSO

Heckman, F. (1993). The social contract. OPUS Publicationserver, University of Bamberg Press, 4, S, 245-246.

Higgins, C. (2012). What Danny Boyle's Olympics opening ceremony said about Britain's cultural landscape. The Guardian, July 28, 2012. Available from: http://www.guardian.co.uk/culture/charlottehigginsblog/2012/jul/28/olympics-2012$\underline{\text { danny-boyle }}$

Hinch, T., Higham, J. (2004). Aspect of Tourism: Sport Tourism Development. Clevedon: Channel View Publication.

Hogan, J. (2003). Staging the nation: gendered and ethnicised discourses of national identity in Olympic opening ceremonies. Sport and Social Issues. 27 (n): 100-123.

Imran, S., Alam, K., Beaumont, N. (2014). Environmental orientations and environmental behaviour: Perceptions of protected area tourism stakeholders. Tourism Management, 40: 290-299.

Jacobson, J. (1997). Perceptions of Britishness. Nations and Nationalism 3(2), pp. 181-199.

Knauer, K., Murray, S. (2000). Britishness and Cultural Studies. Continuity and Changes in Narrating the Nation. Poland: Katowice.

Klausen, A.M. (1999). Olympic Games as performance and public event. The case of the XVII Winter Olympic Games in Norway. UK: Berghahn Books. 
Kaplanidou, K. (2006). Affective Event and Destination Image: Their Influence on Olympic Travellers' Behavioural Intentions. Event Management, 10(2-3):159-173.

Kumar, K. (2003). The making of English national identity. Cambridge University Press.

Lindberg, D. (2007). The beginnings of Western science: the European Scientific tradition in philosophical, religious, and institutional context. Second edition. Chicago: University of Chicago Press.

LOOC (1994). Lillehammer Olympic Organizing Committee. "1994 Winter Olympics $\begin{array}{llll}\text { Report, } & \text { volume } & \text { I". } & \text { Available }\end{array}$ http://library.la84.org/6oic/OfficialReports/1994/E_BOOK1.PDF

Manley, A., Silk, M. (2014). Liquid London: Sporting spectacle, Britishness and ban-optic surveillance. Surveillance and Society, 11(4): 360-376.

Manzenreiter, W. (2010). The Beijing Games in the Western Imagination of China: The Weak Power of Soft Power. Journal of Sport and Social Issues, 34, 1, 29-48.

Miah, A. (2012). "This is for everyone": The London 2012 Olympic Games Opening Ceremony as a cultural celebration. Culture @ the Olympics: issues, trends and perspectives, 14(7): 44-57.

Miles, M.B., Huberman, A.M. (1994). Qualitative data analysis: an expanded sourcebook. London: Sage.

Mobley, A. M. (2008). Sharing the dream: The opening ceremonies of Beijing. Journal of Sport \& Social Issues, 32, 327-332.

Moragas, M. (2009). The Cultural Olympiad of Barcelona in 1992 Good points and bad points. Lessons for the future. [online]. [Accessed 12 ${ }^{\text {th }}$ February 2009]. Available from:http://www.recercat.net/bitstream/2072/9080/1/WP049_eng.pdf.

Morra, I. (2013). Britishness, popular music and national identity: the making of modern Britain. London: Routledge. 
Morgan, N., Pritchard, A. (2004). Meeting the destination branding challenge. In: Morgan, A., Pritchard, A., and Pride, R. ed. Destination branding. Creating the unique destination proposition. $2^{\text {nd }}$ edition. Oxford: Butterworth-Heinemann, pp. 59-78.

Morrow, J.R., Jackson, A.W., Disch, J.G., Mood, D.P. (2005). Measurement and evaluation in human performance. $3^{\text {rd }}$ edition. Champaign, IL: Human Kinetics.

Owen, G. (2002). Call to teach ethnic languages. In: The Times. $7^{\text {th }}$ June 2002.

Parekh, B. (2002). Defining British national identity. Political Quarterly, 71(1): 4-14.

Puijk, R. (1999). Producing Norwegian Culture for Domestic and Foreign Gazes: The Lillehammer Olympic Opening Ceremony. In Klausen, A.M. eds. Olympic Games As Performance and Public Event. The Case of the XVII Winter Olympic Games in Norway. Oxford: Berghahn Books, pp: 97-136.

Rickly-Boyd, J. M. (2012). Authenticity and aura: A Benjaminian approach to tourism. Annals of Tourism Research, 39(1): 269-289.

Robson, C. (2002). Real world research. $2^{\text {nd }}$ Edition. Oxford: Blackwell.

Sealy, W., Wickens, E. (2008). The Potential Impact of Mega Sport Media on the Travel Decision-Making Process and Destination Choice-The Case of Portugal and Euro 2004. Journal of Travel and Tourism Marketing, 24(2-3): 127-137.

Smyth, H. (1994). Marketing the City: The role of flagship projects in urban regeneration. London: Spon.

Silk, M. (2014). The London 2012 Olympics: the cultural politics of urban regeneration. Journal of Urban Cultural Studies, 1(2): 273-293.

Silverman, D. (1993) Interpreting Qualitative Data: Methods for Analysing Talk, Text and Interaction. London: Sage.

Storry, M., Childs, P. (1997). British cultural identities. London: Routledge. 
Gibson, O. (2012). Olympic opening ceremony will recreate countryside with live animals. The Guardian, $20^{\text {th }} \quad$ June 2012 . Available from: http://www.theguardian.com/sport/2012/jun/12/london-2012-olympic-opening-ceremony

Sutherland, M. (2012). British music takes centre stage at Olympics opening ceremony. Rolling Stone, July 28, 2012. Available from: http://www.rollingstone.com/music/news/british-music-takes-center-stage-at-olympicsopening-ceremony-20120728

Thomas, J.R., Nelson, J.K. (2001). Research methods in physical activity. $4^{\text {th }}$ edition. Champaign, IL: Human Kinetics.

Tickle, L. (2011). Want to be a Beefeater? Education: The Guardian. Available from: http://www.theguardian.com/education/2011/jul/04/beefeaters-history-research-notes

Tomlinson, A. (1996). Olympic spectacle: Opening Ceremonies and some paradoxes of globalisation. Media culture Society, 18: 583- 602.

Traganou, J. (2010). National narratives in the opening and closing ceremonies of the Athens Games. Journal of Sport and Social issues, 34:236-251.

Triandafyllidou, A. (2012). Addressing cultural, ethnic and religious diversity challenges in Europe: a comparative overview of 15 European countries. Accept Pluralism Research Project. Tolerance, pluralism, and social cohesion: responding to the challenges of the $21^{\text {st }}$ century. Available from: http://ec.europa.eu/research/social-sciences/pdf/acceptpluralism-addressing-cultural-ethnic-religious-diversity-challenges-in-eu_en.pdf

UK Government (2016). How to become a British citizen. Available from: www.gov.uk University of Bristol (2012). Bristol Morris dancers take to the stage at the Olympic closing $\begin{array}{llll}\text { ceremony. } & 14^{\text {th }} \quad \text { August } & \text { 2012 } & \text { Available } \\ & \text { from: }\end{array}$ http://www.bristol.ac.uk/news/2012/8721.html 
VisitLondon (2012). Top 10 best bits from the London 2012 Olympic Games opening ceremony. Available from: $\underline{w w w . v i s i t l o n d o n . c o m}$

Weed, M. (2008). Olympic Tourism. UK: Butterworth-Heinemann.

Werbner, P. (2013). Everyday multiculturalism: theorising the difference between intersectionality and multiple identities, Ethnicities, 13, 401-419.

Williams, A. M; Hall, C. M; and Lew, A.A. (2014). Theoretical and Methodological Challenges for Tourism. In Lew, A.A.; Hall, C. Michael. and Williams, Allan. M., (Eds.) The Wiley-Blackwell Companion to Tourism, pp. 625-634. London: Blackwell (Blackwell Companions Series).

Xin, S., Tribe, J., and Chambers, D. (2013). Conceptual Research in Tourism. Annals of Tourism Research, 41, 66-88.

Xu, X. (2006), Modernizing China in the Olympic Spotlight: China's National Identity and the 2008 Beijing Olympiad. The Editorial Board of the Sociological Review, 90-107.

Xu, G. (2008). Olympic dreams: China and sports, 1895-2008. The President and Fellows of Harvard College.

Zhu, Y. (2012) Performing Heritage: Rethinking Authenticity in Tourism. Annals of Tourism Research, 39 (3):1495-1513. 